\title{
Strategies for Lease Volume Enhancement: Study of the Nigeria Lease Market 2001-2011
}

\author{
OKO, A. E. NDU ${ }^{1} \&$ Isu, Hamilton $\mathrm{O}^{2}$ \\ ${ }^{1}$ Department of Marketing, Abia State University, Uturu, Nigeria \\ ${ }^{2}$ Department of Banking and Finance, Abia State University, Uturu, Nigeria \\ Correspondence: OKO, A. E. NDU, Department of Marketing, Abia State University, Uturu, Nigeria. Tel: \\ 080-5785-1630. E-mail: a.e_nduoko@yahoo.com
}

Received: May 6, 2013

Accepted: June 28, 2013

Online Published: July 25, 2013

doi:10.5539/ibr.v6n8p38

URL: http://dx.doi.org/10.5539/ibr.v6n8p38

\begin{abstract}
The Nigeria lease market given the relatively poor per capita income, but willingness among the high economic population to spend and the growth in the oil gas industry as well as road transportation compared to other African nations ought to record higher volume of lease transactions. Contrary to expectations, the lease volume has remained low. It is in doubt if the total lease volume recorded in Nigeria would have generated enough profit to sustain the number of firms that are actively involved in sales-(marketing) of lease services; if these firms were solely involved in lease businesses. The relatively low volume of lease transactions suggests that the market capacities are grossly under utilized. This is evidenced as the work compared the situation in Nigeria with South Africa based on survey research method; with special interest on the marketing principles, strategies and policies for lease service marketing. Results show that the Nigeria lease marketing activities experience inefficiency sequel to poor control of administrative and legal costs, low level of customer services among others. Hence lease sales volume is low. Thus strategies for lease volume enhancement as recommendations are discussed to include: creation of competitive advantage, specialization in lease marketing, customer services flexibility, enhanced funding ability among others.
\end{abstract}

Keywords: lessor, lessee, specialization, diversification, flexibility, competitive advantage, customer satisfaction

\section{Introduction}

Lease volume enhancement relates to market turnover, hence measures the relative rapidity of lease market and marketing activities over a specified time frame. Lease volume like market share relates to the ratio of a firms sales revenue or unit sales to those of the industry (competitor plus the firm itself)-Berkowitz, Kerin, Hartley and Rudelius (2000:369). Several factors could be responsible for enhanced lease sales volume. Among these is the ability of the lessor to create, sustain and enhance customer satisfaction. It is therefore important that manufacturers and dealers on lease products should employ marketing strategies for the boasting of the sales of their products, either based on parent or self financing or through vendor leasing agreements.

\section{Frame Work of the Study}

Nigeria with her very low level of per capita income of \$2 748 compared with Ghana and Cameroun of \$10 748 and \$10 758 respectively (World Development Report 2010), is expressing difficulty in capital accumulation for long term investments, dependency on foreign aid and counter part financing for industrial development is also being challenged by the country's rating by transparence international. Given these difficulties, alternative approach to the quest for industrial development based on the acquisition and use of productive technology is equipment leasing.

A study of twenty four (24) industries in Nigeria shows that only 11 (11 of 45.8\%) were involved in the use of lease based productive technologies-Oko (2008). This result is an indication that Nigerians are yet to accept for appreciation the benefits of leasing compared to other strategies of acquisition of productive technologies.

This poor level of lease serve consumption is shown as the transactions in the banking industry are compared with those of the equipment lease market vis-à-vis loans volume for equipment acquisition and lease volume for the period 2001 to 2011 as shown in table 1 below: 
Table 1. Volume of lease financing versus loans in Nigeria 2000-2011

\begin{tabular}{|c|c|c|c|c|c|}
\hline Year & Total lease volume & $\begin{array}{c}\% \text { Growth } \\
\text { Rate }\end{array}$ & Total loan volume & $\begin{array}{c}\text { \% Growth } \\
\text { Rate }\end{array}$ & $\begin{array}{c}\text { Ratio of lease volume } \\
\text { to loan volume }\end{array}$ \\
\hline & N 000 & & N 000 & & \\
\hline 2000 & 19645315 & & 6258782700 & & $1: 319$ \\
\hline 2001 & 32166425 & 64.0 & 8914605900 & 42.4 & $1: 277$ \\
\hline 2002 & 46336877 & 50.0 & 12694398802 & 45.1 & $1: 268$ \\
\hline 2003 & 59848795 & 24.0 & 20752032300 & 60.4 & $1: 268$ \\
\hline 2004 & 78863069 & 31.8 & 30575187053 & 47.4 & $1: 347$ \\
\hline 2005 & 115140079 & 46.0 & 46474284320 & 52.0 & $1: 388$ \\
\hline 2006 & 189881130 & 65.0 & 73894112069 & 59.0 & $1: 389$ \\
\hline 2007 & 245700000 & 30.0 & 124142108276 & 68.0 & $1: 505$ \\
\hline 2008 & 348894000 & 42.0 & 222214373814 & 79.0 & $1: 637$ \\
\hline 2009 & 445265650 & 28.0 & 428873471461 & 93.0 & $1: 963$ \\
\hline 2010 & 537907638 & 21.0 & 904923314483 & 111.0 & $1: 1682$ \\
\hline 2011 & 622907638 & 15.8 & 2099422112800 & 132.0 & $1: 3370$ \\
\hline
\end{tabular}

Source: Afro Lease News Report, (2006) Issue 1, volume 1, ELAN (2009) Volume 11, Number 1 (2012) Volume 11 Number 1 and Central Bank of Nigeria Statistical 2011.

The percentage difference between bank loans volume for equipment acquisition and lease volume over the period is much as shown in table 1 . This point to the fact that the banking industry is competition prone compared to the equipment lease market.

The statistics show that the total equipment lease services volume in Nigeria increased from N1 965 billion in 2000 to N7 887 billion in the year 2004, and 622.96 in 2011 while total loans for capital acquisition increased from N625 878 billion naira in the year 2000 to N3 058312 billion naira in year 2004 and 2.09 Trillion in 2011. The volume of equipment lease financing represents only about $1.2 \%$ of total loans granted in Nigeria-Abshiya (2006). Abashiya (2008).

Table 2a. Banking industry and fund management (lease) industry compared: 2001-2006

\begin{tabular}{lcccc}
\hline Industry & $\begin{array}{c}\text { Number of } \\
\text { Companies }\end{array}$ & $\begin{array}{c}\text { Number of } \\
\text { Deals }\end{array}$ & Number of Shares \\
\hline Banking & 18 & 3.397 & 139525450 & 1049116311.11 \\
Fund Management & 1 & 14 & 1737065 & $1: 80$ \\
Ratio & $1: 18$ & $1: 243$ & $1: 601$ \\
\hline
\end{tabular}

Source: The Lagos Stock Market Last Week. This Day December 18, 2006.

A comparative analysis of the banking (deposit money bank) industry and the (fund management) leasing industry, on table 2a shows that 18 companies with 3397 deals 139525450 shares valued at N104 911b 31111 were traded on the floor of the Lagos stock market in the banking industry while 1 (one) company $\mathrm{C} \&$ I Leasing Plc. with 14 deals, 1737065 shares valued at N174 578565 in the (fund management) leasing industry were traded (This Day; December 18, 2006). 
Table2b. Banking Industry and fund management (lease) industry compared: 2007-2012

\begin{tabular}{lcccc}
\hline Industry & $\begin{array}{c}\text { Number of } \\
\text { Companies }\end{array}$ & $\begin{array}{c}\text { Number of } \\
\text { Deals }\end{array}$ & Number of Shares & Value of Shares \\
\hline Banking & 15 & 1748 & $130,452,723$ & $664,651.000$ \\
Fund Management & 1 & 8 & 279,405 & 140,000 \\
Ratio & $1: 15$ & $1: 218.5$ & $1: 466.90$ & $1: 4747.5$ \\
\hline
\end{tabular}

Source: The Daily Stock Survey as at 1st February 2012. Daily Sun, February 2, 2012.

The ratio for 2012 as shown in table $2 \mathrm{~b}$ are 1:15 for companies, 1:218.5 for deals, 1:466.9 for number of shares and 1:4747.5 for value of shares-Daily Sun-February 2, 2012. This shows the obvious poor performance of lease firms compared to firms in the banking industry.

Based on to tables $2 \mathrm{a}$ and $2 \mathrm{~b}$, the banking (deposit money banks) industry is far ahead of the fund management-(Leasing) industry in contributing to economic growth and development in Nigeria. While the ratio of companies is 1:18, the ratio of deals is 1:243, ratio of number and value of shares traded are 1:80 and 1:601 respectively. The question is; why inspite of the relatively higher rate of profitability and ability to ensure consumer satisfaction among equipment lease based organizations compared to non-lease based organizations is the acceptability (marketability) of equipment lease services low as explained and evidenced above-Oko and Ogwo (2012), Oko and Etuk (2012) and Oko and Aham (2012). The reasons for this much difference in the acceptance of banking sourced fund compared to leasing constitute challenges to the marketing of equipment lease services in Nigeria.

Globally, the lease growth rate is over $10 \%$ compounded annually for the past 5 years. There has been important growth in the leasing industries of the small and medium size countries as shown in literature, but the biggest nations of United States, Japan and United Kingdom have continued to dominate lead position-Porter (2006).

South Africa as one among the lead lease industries (markets) of the world is likely to continue to do better than Nigeria inspite of the economic population and growth in the oil and gas industrial sector of Nigeria. The lease volume of South Africa and Nigeria for the period 2001-2004 is shown in Table 3.

Based on table 3, the South Africa Index shows an appreciable level of marketing oriented activities in lease services exchange compared to Nigeria.

For the period under review, the Nigeria lease market showed a declining growth rate of $63.7 \%, 50.60 \%$, and $24.0 \%$ for 2001, 2002 and 2003 respectively and growth of $31.8 \%$ in 2004 over 2003. For South Africa, no growth was recorded in 2002 over 2001; however 2003 recorded 22.2\% growth while 2004 experienced 15\% declined in growth rate.

Table 3. South Africa and Nigeria lease volume comparison 2001-2004 (US \$ in Billion)

\begin{tabular}{|c|c|c|c|c|c|c|c|c|}
\hline \multirow{3}{*}{ Country } & \multicolumn{4}{|l|}{2001 Annual } & \multicolumn{2}{|l|}{2003} & \multicolumn{2}{|l|}{2004 Annual } \\
\hline & Volume & \% Growth & 2002 & $\%$ Growth & & \% Growth & Volume & $\%$ Growth \\
\hline & & & & & Volume & & & \\
\hline South Africa & 2.79 & 25.4 & 2.79 & 0.0 & 4.61 & 22.2 & 6.60 & 15 \\
\hline Nigeria & 0.27 & 63.7 & 0.37 & 50.6 & 0.43 & 24.0 & 0.59 & 31.8 \\
\hline
\end{tabular}

Source: ELAN PUBLICATIONS 2000-2005.

Over the period of review, average lease volume transaction for Nigeria was 0.42 US Billion Dollars (below half a billion US dollar) while South Africa recorded in average 4.20 US billion Dollars. Comparing the economic conditions of both countries and the active population, Nigeria is expected to show a higher volume of lease transaction compared to South Africa. But the reverse is the case. Identification of this reason for this poor lease market performance is the crux of this exercise. 
Comparing the level of lease service consumption in Nigeria with the banking services; in tables $2.0 \mathrm{a}$ and $2.0 \mathrm{~b}$ and Nigeria and other nations especially South Africa Table 3 shows that leasing is yet to be appreciated in Nigeria inspite of its obvious benefits. This work is focused at identifying reasons for low level of equipment lease service consumption in Nigeria as bases for strategizing for lease volume consumption enhancement.

\section{Objective of the Study}

This work is aimed at identifying the causes of low level of lease service consumption in Nigeria as well as offer strategies for enhanced adoption of leasing as alternative to straight, hire-purchase, installmental and credit purchases of productive technologies.

\section{Methodology}

This, as a cross sectional research design work, it surveyed the activities of lessors and lessees and non-lessors and non-lessees as providers and consumers respectively of productive equipment, technologies and finance in the industrial sectors of Nigeria and South Africa as presented in table 4.

Industrial sub- sectors considered are Breweries; Building materials; Food, Beverages and Tobacco; Petroleum (marketing); Conglomerates, Health; Construction, and Chemical and Paints industries.

\section{1 Research Hypothesis}

This work has a single hypothesis projected in null form thus:

H0: There is no significant difference in the rate (level) of adoption of marketing principles, strategies and policies between Nigeria and South Africa in the marketing of lease services.

\subsection{Research Design and Scope of Work}

It appraised the level of the adoption of marketing principles, strategies and policies in the banking industry vis-à-vis the lease industry for the period of 2001-2011 and compared same with the situation in South Africa. Thus it is considered a descriptive (survey) research on cross sectional basis. Equal numbers of samples were drawn from both industries from marketers and consumers of lease services and on line questions were filed for consumers and marketers of equipment lease services in South Africa.

Samples were simple randomly selected as sizes of samples were determined based on yard mathematical notation of:

$$
n=\frac{N}{1+N(\alpha)^{2}}
$$

$$
\begin{aligned}
& \text { Where } \mathrm{N} \text { = population size } \\
& \qquad \begin{aligned}
\mathrm{n} & =\text { samples size } \\
& \alpha=\text { permissible level of sampling error at a permissible sample error level of } 10 \%
\end{aligned}
\end{aligned}
$$

Population of this study is seventy two (72) corporate members of Equipment Leasing Association of Nigeria (ELAN), forty eight (48) of which are equipment lease bias and the fifteen (15) banks that succeeded beyond the 2011 bank consolidation exercise in Nigeria.

Fourteen (14) lease based firms and banks were respectively selected for Nigeria and ten (10) lease based firms and banks respectively from South Africa. Thus a total sample element of forth-eight (48). Two (2) copies of questionnaire were administered on each of the corporate consumers and marketers of the (lease) services as the research sample elements. Hypothesis was tested based t-test of difference in populations shown as:

Where: $\overline{\mathrm{X} 1}=$ mean of the first category 1 sample

$$
t=\frac{\overline{X 1}-\overline{X 2}}{\sqrt{\frac{s_{1}^{2}}{n_{1}}+\frac{s_{2}^{2}}{n_{2}}}}
$$

$\overline{\overline{\mathrm{X} 2}}=$ mean of the second category 1 sample

$\mathrm{n}_{1}=$ sample size of the first category 1 sample

$\mathrm{n}_{2}=$ Sample size of the second 1 category sample 


$$
\begin{aligned}
& \mathrm{S}_{1}^{2}=\text { standard deviation }\left(\mathrm{S}_{1}\right) \text { of the first category of sample } \\
& \mathrm{S}_{2}^{2}=\text { standard deviation }\left(\mathrm{S}_{2}\right) \text { of the second category of sample }
\end{aligned}
$$

\section{Data Presentation}

Data were sourced based on copies of Questionnaire as administered on lease and non lease services marketers and consumers in Nigeria and South Africa are presented thus:

Table 4. Rating related relevant variables in the marketing of lease services in Nigeria and South Africa-a

\begin{tabular}{|c|c|c|}
\hline Relevant Issues & Nigeria & South Africa \\
\hline \multicolumn{3}{|l|}{ Lessors } \\
\hline \multicolumn{3}{|l|}{ Competitive Advantage Variables: } \\
\hline Assessment of lease market /marketing operations in terms of size of tickets & 197 & 191 \\
\hline Degree of adoption of market segmentation principles & 251 & 275 \\
\hline Degree of target market specialization & 208 & 214 \\
\hline Degree of shift in and outside different lease markets & 194 & 217 \\
\hline Quality of corporate personnel & 185 & 205 \\
\hline Integration of features of marketing in market offers & 160 & 210 \\
\hline \multicolumn{3}{|l|}{ Specialization } \\
\hline Degree to which niche marketing principles are adopted & 242 & 182 \\
\hline Degree of concentration of efforts on particular lease market segment & 264 & 162 \\
\hline Degree to which lease market activities influence innovation and innovative marketing & 216 & 132 \\
\hline Impact of administrative and legal costs in corporate profitability & 221 & 153 \\
\hline Degree of consistency in realization of corporate objectives based target market specialization & 260 & 235 \\
\hline \multicolumn{3}{|l|}{ Efficiency } \\
\hline \multicolumn{3}{|l|}{ Degree of impact of the underlisted variables on corporate operational efficiency } \\
\hline Reliability of source of fund & 209 & 202 \\
\hline Cost of fund & 221 & 232 \\
\hline Diversification of sources of fund & 242 & 198 \\
\hline Finance under & 264 & 202 \\
\hline Consistency of methods and sources of funding with business plan & 216 & 230 \\
\hline \multicolumn{3}{|l|}{ Lessees } \\
\hline \multicolumn{3}{|l|}{ Assessment of lease organization's ability to satisfy lessees in terms of: } \\
\hline Quality of customer service & 163 & 188 \\
\hline Quality of customer care service & 124 & 172 \\
\hline Convenience in offer & 136 & 168 \\
\hline Flexibility of lease terms & 122 & 190 \\
\hline Ability to meet lessee's (consumers') expectations & 141 & 192 \\
\hline Completeness of offer-warranties, repair and maintenance services. & 120 & 184 \\
\hline Choice of product & 130 & 160 \\
\hline
\end{tabular}
comparison

Source: Field Survey Data 2012.

\section{Data Analysis}

The analysis of data is summarized as shown in table 5. 
Table 5. Analysis of data as presented in table 4

\begin{tabular}{|c|c|c|c|}
\hline $\mathrm{X}_{1}$ & $\mathrm{X}_{1}^{2}$ & $\mathrm{X}_{2}$ & $\mathrm{X}_{2}^{2}$ \\
\hline \multicolumn{4}{|c|}{ Competitive Advantage } \\
\hline 197 & 38809 & 191 & 36481 \\
\hline 215 & 46225 & 275 & 75625 \\
\hline 208 & 43264 & 214 & 45796 \\
\hline 194 & 37636 & 217 & 47089 \\
\hline 185 & 34225 & 205 & 42025 \\
\hline 160 & 25600 & 210 & 44100 \\
\hline$\Sigma x_{1}^{1}=1159$ & $\Sigma \mathrm{x}_{1}^{2}=225759$ & $\Sigma \mathrm{x}_{2}=1312$ & $\Sigma x_{2}^{2}=291116$ \\
\hline$X_{1}=193$ & & $X_{2}=218$ & \\
\hline $\mathrm{S}_{1}=19.38$ & & $\mathrm{~S}_{2}=29.07$ & \\
\hline \multicolumn{4}{|l|}{ Specialization } \\
\hline 242 & 58564 & 182 & 33124 \\
\hline 264 & 69696 & 162 & 26244 \\
\hline 216 & 46656 & 132 & 17424 \\
\hline 221 & 48841 & 153 & 23409 \\
\hline 260 & 67600 & 235 & 55225 \\
\hline$\Sigma X 1=1203$ & $\Sigma X_{1}^{2}=291357$ & $\Sigma \mathrm{X}_{2}=864$ & $\Sigma X_{2}^{2}=155426$ \\
\hline$X_{1}=240.6$ & & $\mathrm{X}_{2}=172.8$ & \\
\hline $\mathrm{S}_{1}=21.88$ & & $\mathrm{~S}_{2}=39.13$ & \\
\hline \multicolumn{4}{|l|}{ Efficiency } \\
\hline 209 & 43681 & 202 & 40804 \\
\hline 221 & 48841 & 232 & 53824 \\
\hline 242 & 58564 & 198 & 39204 \\
\hline 264 & 69696 & 202 & 40804 \\
\hline 216 & 46656 & 230 & 52900 \\
\hline$\Sigma \mathrm{X}_{1}=914$ & $\Sigma \mathrm{X}_{2}^{1}=228138$ & $\Sigma \mathrm{X}_{2}=1064$ & $\Sigma X_{2}^{2}=227536$ \\
\hline $\mathrm{X}_{1}=182.8$ & & $\mathrm{X}_{2}=212.8$ & \\
\hline $\mathrm{S}_{1}=431.70$ & & $\mathrm{~S}_{2}=16.70$ & \\
\hline \multicolumn{4}{|l|}{ Customer Satisfaction } \\
\hline 163 & 26569 & 188 & 35344 \\
\hline 124 & 15376 & 172 & 29584 \\
\hline 136 & 18496 & 168 & 28224 \\
\hline 122 & 14884 & 120 & 36100 \\
\hline 141 & 19881 & 192 & 36864 \\
\hline 120 & 14400 & 184 & 33856 \\
\hline 130 & 16900 & 160 & 25600 \\
\hline$\Sigma \mathrm{x}_{1}=936$ & $\Sigma \mathrm{x}_{2}=126506$ & $\Sigma x=1254$ & $\Sigma x=225572$ \\
\hline$X 1=133.7$ & & $\mathrm{X} 2=179$ & \\
\hline $\mathrm{S}_{1}=14.99$ & & $\mathrm{~S}_{2}=12.4$ & \\
\hline
\end{tabular}

B.O Data Analysis 
Thus let Nigeria be donated by $\mathrm{x}_{1}$ and South Africa $\mathrm{x}_{2 .}$. Sourced data are analyzed thus:

Substituting t- test formula:

$$
t=\frac{\overline{X 1}-\overline{X 2}}{\sqrt{\frac{s_{1}^{2}}{n_{1}}+\frac{s_{2}^{2}}{n_{2}}}}
$$

For the 4 bases of evaluation, in table 5, the results are shown in summary in table 6

Table 6. Summary of analysis shown in table 5

\begin{tabular}{cccccccc}
\hline \multicolumn{2}{c}{ Competitive Advantage } & \multicolumn{2}{c}{ Specialization } & \multicolumn{2}{c}{ Efficiency } & \multicolumn{2}{c}{ Customer satisfaction } \\
\hline 78.41 & adf & 19.41 & odf & 3.17 & odf & 1.97 & odf \\
18 & 1.81 & 8 & 1.86 & 8 & 1.86 & 12 & 1.78 \\
\hline
\end{tabular}

The decision rule is to accept the null hypothesis if the computed (calculated) ' $t$ ' value is less than the critical (table) value, otherwise the null hypothesis is rejected.

The hypothesis formulated is thus:

$\mathrm{H} 0: \quad \rightarrow 1=\rightarrow 2$

There is no significant different in the rate (level) of adoption of marketing principles, strategies and policies between Nigeria and South Africa in the marketing of lease services.

Ho: $\quad \rightarrow 1 \neq \rightarrow 2$

There is a significant difference in the rate (level) of adoption of marketing principles, strategies and policies between Nigeria and South Africa in the marketing of lease services.

Since the computed ' $\mathrm{t}$ ' statistics of $78.45,19.41,3.17$ and 1.97 for the various variables considered are greater than the critical values of $1.81,1.86,1.86$ and 1.78 respectively; the accepted conclusion is that there is a significant difference in the rate and level of adoption of marketing principles, strategies and policies between Nigeria and South Africa in the marketing of lease services as null hypothesis. This is at 0.05 level of confidence.

\section{Discussion of Findings}

Based on the findings of this study, the discourse below is considered vital to lease volume enhancement using Nigeria as target.

Lease- Sales volume enhancement in the lease industry has two basic strategic approaches namely:

- Increase in capital spending and or

- Decrease in interest rate

These two strategies have corresponding impacts on each other, thus their usage evokes some degree of care. However, whether through a captive subsidiary or through a 3rd (third) party leasing company; manufacturers have often enjoyed improvement in sales volume and gross profit by offering lease products to customers. This trend is expected to continue as most leasing companies make vendor programmes available to their customers given that these vendors have continued to recognize the benefits of vendor programme- Halladay and Amembal (1995:580-589).

With the strategy of lease volume enhancement, the lessor should create confidence in the usage of the equipment (assets) through offer of quality product and services. Lease volume enhancement is achievable based on the emergence of international market, sequel to cross border leasing; which is one of the operative ways of expanding the lease business and increasing the market for locally manufactured equipment and assets-Ndu (2003: 20-23).

Cross border leasing, in addition to expanding national export market, encourages international cooperation. This is however possible where the lessor (manufacturer) has competitive advantage in the marketing of its offer. Further impetus to the above assertion is this: Cross border export-linked lease financing assists the importing company in improving its cash flow and liquidity, as well as in paying for the asset out of income generated by 
their use-Ndu (2003: 20-23).

The Economic Community of West Africa (ECOWAS) and indeed, the total Africa markets are yet to be exploited through cross border export-link financing; and these opportunities are tremendous considering the cash-stripped situation of most African countries and the inability to pay outright cash for high ticket capital equipment that are highly needed for rapid industrialization-Ndu (2003:20-23).

The Nigeria lease market's quest for cross border lease technology should be balanced with strategies aimed at enhancing the quality of lease export for the desired lease volume enhancement. Lease volume enhancement is equally achievable sequel to improving economic policies of most governments-Nigeria inclusive. The reform activities of the government through the Nigerian Investment Promotion Commission (NIPC) in conjunction with the World Bank are aimed at addressing issues relating to lease enabling environment; the tax law and the accounting policies amendments proposed, no doubt will all encourage lessors and enhance the volume of activities. This is believed to be possible as these structural changes will improve on the difficulties associated with lease capital sourcing, provide lower lease payments and ensure flexibility in lease rental payments.

The above supports the assertion that lessors are now engaged in various lease arrangements, offering different types of lease products in response to the needs of the lessees and present economic realities-Olusoga (2005:12-14). The expansion of leasing activities is a reflection of the increasing level of lease consciousness in the country. However, the continuous growth of the industry depends to a very large extent on a healthier environment-Olusoga (2005:12-14); and ability to identify and manage the marketing challenges of this sub-sector of the finance market.

Another very important factor influence in lease volume enhancement is a shift of emphasis from industrial to household equipment leasing; creating interest for consumer leasing. In Nigeria, lease vendors of various leaseable items are active in consumer leasing in order to boast sales. Consumer leasing, lease authorities confirm has brought comfort to many Nigerians in terms of providing desired assets that may not have been owned based on purchase transactions-ELAN (2004:7-9). To sustain this growth, it is imperative that lessors should continue to boost lessees' confidence in the product through professionalism, dynamic and easy to run customized transactions, based on relationship and referral marketing techniques. These are vital area of deficit in the Nigerian equipment lease services marketing. This deficit infringe on the quality of lease services offer.

It is important for the lessor to understand the trade off effect between large volume transactions and specialized lease market activities; for ability to maximize lease consumer expectance benefits, profitability, and to create class distinctions between corporate products and those of competitors.

\section{Summary/Conclusion}

Expansion in lease (leasing) volume and activities is a reflection of the increasing level of lease consciousness in the country. To achieve this, economic adjustments and re-adjustments are likely to give more impetus to further growth in lease activities as enhanced lease financer and lease relationships are experienced, improvement in the use of lease information, technology, quality market competition and quality lease project appraisal. Based on the above, improved return on investment resulting from quality lease residual value risk management will be achieved-Abashiya (2005: 15-19, 26-27). Sequel to above, the discussed lease volume enhancement strategies are advocated for lessors in Nigeria.

\section{Discussions and Recommendations on the Nigeria Lease Market}

In all de-regulated economies, the forces of demand and supply do inter play for price determination. Price of a market offer is thus influenced by the cost of production, the environmental factors and the expected returns on investment of the entrepreneur among others. From the consumers' point of view, price of factor output is influenced by the consumers' income and expectations given the offer. Sequel to the above, the producers including providers of lease services compete to satisfy the lessee for the purpose of profit making and remaining relevant in the market, as these are indices of success.

In the competitive market, the lessors have to manipulate variables for success. These variables are often policy and or strategy based and could include the following:

\subsection{Creation (Achievement) of Competitive Advantage}

Competitive advantage as a unique strength relative to competitors is often based on quality, time, cost and or innovation-Kerin and Robert (1997: 2-3) and depends on special capabilities resulting from corporate personnel, resources or functional units as essential means of achieving success-Kerin and Peterson (1997: 2-3) and Abell (1980), Stalk and Shulman (1992: 57-69). This is even so in the lease market. 
Lessor may gain advantage over (competitors) sellers of equipment based on the size of operation especially for niche marketing. They may offer all services and products to small or large market, based on distinctive offers. Product quality if properly managed in core and supplementary features of lease, has the propensity to achieving competitive advantage, or at least help the lease firm remain competitive with other firms that have focused on quality improvement-Eskildson (1995:25-38). Berkowitz, Kerin, Hartley and Rudelius (2000: 40), stressing the importance of quality in corporate drive for competitive advantage advocate for quality personnel training, process improvement and bench marketing and integration of features of quality in the offer. Thus Lessors are encouraged to be quality focused in offer.

Competitive advantage may also be gained based on lower cost sourced financial facilities or through diversified lease investments. This is most difficult in Nigeria as the limited lessor resources are wrongfully invested in the three (3) core lease sub-segments without market specialization.

\subsection{Specialization}

No longer will it be possible for lessor to provide all types of leasing facilities in all markets, there is need for niche marketing, as this will enhance chances of competitive advantage in the size of transaction, geographical area and technical expertise-Lemo (2003: 15-20).

Regardless of the niche, lease experts are of the opinion that specialization can lead to success in a market through superior knowledge, uncompromising service and value added products.-Halladay and Amembal (1995). Specialization enhances internal economy of scale and efficiency in resource allocation and utilization, hence assures success in lease operations through reduced market risk of equipment. Specialization, based on market segmentation and niche marketing principles is factor influence to success in marketing -Lemo (2003: 15-20) and Halladay and Amembal (1995: 580-590).

Specialized lessors support the provision of better maintenance services, prompt replacement of equipment broken down, procurement of insurance services at favourable rates and many other services -Abashiya (2005:26-27). It also increases productivity, as Lessor effort on either of the different types of equipment that can be leased and their price range given the three core segments of leasing-small, medium and large ticket market respectively-Ndakotsu (2000:31), become more proficient-Churchill Jr.; Ford and Walker Jr. (1997: 108). Lease market specialization could also consider financial institutions; independent lessors and captive finance organizations-Bashir (2005:16-24). Lease consumer service has its hallmark as customer relationships; innovation in characteristics of market offer; quality and efficiency in service delivery-Berkowitz, Kerin, Hartley and Rudelius (2000: 32). Lessors however should strive for a right balance among these four features of lease consumer services as building blocks for success and lease volume enhancement-Hall and Jones (1998).

\subsection{Customer Service and Flexibility}

It is easy in a world of interest rate, lease rate and residual value to forget that leasing is to a large degree, a business of relationship-Halladay and Amembal (1995: 580-589). People do business with those they like and trust. Good relationship begins with quality customer services, hence lessors with good lessee relationships adapt to the specific needs of the lessees-Ndu (2004: 10-15). It is important to note that the size of the lessor firm does not ensure lessee loyalty, if the services are not in consonance with the expectations of the lessee. Lease flexibility is expected to extend to lease payment schedules of step leases and for skipped payment leases.

Lease flexibility also guarantees the lessee the right to choice of products and response to changes in terms of agreement and product replacements. These are considered conditions for (customers) lessees in lessor selection. It as well enhances lessors' success as lessee loyalty and lease volume enhancement are guaranteed. This unfortunately is not considered an important feature of lessors' advertisements in Nigeria.

\subsection{Funding Ability}

Lessors' success is reasonably influenced by ability to establish and maintain premier funding. Thus it is important that the lessor should consider technical and economic efficiencies as bases for viability while efficiency considers the ability of the assets to satisfy the operational needs of the lessee within time frame without decline in the quality of output-Oko (2002:133-136); economic efficiency in favour of the lessor has to do with the following:

- Reliable source of funds

- Low cost of funds and

- Diversification of sources of funds

Approved sources and methods of funding lease should be consistent with the business plan. This is assured 
through strong funding programme and constant monitoring of the programme for long term success.

Lessors should harness the opportunities resulting from changes associated with globalization of business and advances in technological platform that have given borrowers the grace to diversify their sources of funding and to seek more cost efficient funding structures that have enhanced their ability to compete-Nwazu (2000: 18). Given the lease industrial market competition for funds, a proper integration of marketing, underwriting, finance and management functions are required-Sandersonn (2004: 32-35).

\subsection{Control of Back-Office Cost}

It is real enduring success in business to do with revenue growth and market share-O;Shea and Madigani (1997); revenue however cannot grow simultaneously with cost for market success. It is important that the periodic cash flow should be adequate to cover overhead cost favourably. Cost incurred in administrative and legal issues must be reasonably controlled; debts settlement must be based on scale of preference for economy of scale as strategy and a more streamlined workforce are two strategies that have helped lessors achieve higher margins in this very competitive market place-Hallladay and Amembal (1995: 580=589).

\subsection{Adaptability to Market Shift}

For desired level of success, leasing companies must within reasonable time frame, be able to effectively shift in and out of different markets as profitability change or when the markets experience shifts themselves. This however must consider the consonance existing between the sub markets of the lease industry-Halladay and Amembal (1995: 580-589). Lessors in Nigeria remain in operation in the same market segment over the years irrespective of need for market shifts.

\subsection{Maintenance of Objectives}

Marketing objective is the target which the lease firm seeks to achieve through marketing action. It establishes the basis for all marketing efforts-Agbonifoh, Ogwo, Nnolim and Nkamnebe (2007: 310). No arbitrary rules should be set regarding the nature of lease organization's objective-Luck and Ferrell (1979: 30); they should be an accurate representation of the aspirations and set of values of its ruling powers. Lease firms objectives should consider two sets of variables-the dimensions or kinds of factors and the market aspiration level or height. While aspiration may relate to lease market growth rate projection, the dimension factor may relate to resource allocation objectives necessary to achieve the growth rate.

Lease firms operating for success, should as a matter of importance and necessity, on continuous and constant basis, evaluate the market place and adopt and adapt new strategies to remain competitive and achieve objectives.

It is however important that the overall philosophies vital for the generation of success be maintained and sustained and where necessary according to the dynamisms of the market be fine tuned. These philosophies should not be replaced or forgotten, unless however where they are inconsistent with internal and external lease firm and market variables.

\section{References}

Abashiya, R. Z. (2005). Banks' Consolidation: Its Impact on the Leasing Industry. Leasing Today-A Quarterly Newsletter of Equipment Leasing Association of Nigeria, 8(1), 15-19.

Abell, D. F. (1980). Defining the Business: Englewood Cliffs. New Jersey: Prentice-Hall.

Agbonifoh, B. A., Ogwo, E. O., Nnolim, D. A., \& Nkamnebe, A. D. (2007). Marketing in Nigeria Concepts, Principles and Decisions (2nd ed.). Port Harcourt: Afrtowers Books.

Bashir, M. M. (2005). The Strategic Management of a Leasing Company, Leasing Turns "Honey Pot" for Investors. Leasing Today-A Quarterly Newsletter of Equipment Leasing Association of Nigeria, 8(2), 16-24.

Berkowitz, E. N., Kerin, R. A., Hartley, S. W., \& Rudelius, W. (2000). Marketing (6th ed.). St. Louis Irwin: McGraw-Hill.

Churchill, G. A., Jr. Ford, N. M., \& Walker, O. C. Jr. (1997). Sales Force Management (5th ed.). Misscuri Irwin: McGraw-Hill.

Eskildson, L. (1995). TQM's Role in Corporate Success: Analyzing the Evidence. National Productivity Review, Autumn, 25-38. http://dx.doi.org/10.1002/npr.4040140405

Halladay, S. D., \& Amembal, S. P. (1995). The Hand Book on Equipment Leasing. USA: Salt Lake Publishers Press. 
Hill, C. W. I., \& Jones, G. R. (1998). Strategies Management: An Integrated Approach (4th ed.). Boston: Houghton-Mifflin.

Kerin, R. A., \& Peterson, R. A. (1997). Strategic Marketing Problems: Case and Comments (8th ed.). Englewood Cliffs, New Jersey: Prentice Hall, 2-3.

Luck, D. J., \& Ferrel, O. C. (1979). Marketing Strategy and Plans. Englewood Cliffs, New Jersey: Prentice-Hall.

Ndakotsu, L. (2000). Lease Financing. Overview of Recent Trends and Developments Funding Lease in Nigeria. The Ideal vs Reality. Leasing A Quarterly Newsletter of Equipment Leasing Association of Nigeria, 5(2) 31-34.

Ndu, E. (2003). Understanding the Equipment Leasing Product, Creating Wealth Through Leasing. Leasing Today - A Quarterly Newsletter of Equipment Leasing Association of Nigeria, 6(1), 15-20.

Ndu, E. (2004). Equipment Leasing and The Oil and Gas Industry- The Quest for an Enabling Environment for Leasing in Nigeria. Leasing Today-A Quarterly Newsletter of Equipment Leasing Association of Nigeria, $8(1), 10-15$.

Nwaeze, G. (2000). The Quest for Appropriate Funding Structure for the Nigerian Leasing Industry. Funding Lease in Nigeria. The Ideal vs Reality. Lease Today - A Quarterly Newsletter of Equipment Leasing Association of Nigeria, 5(2), 8.

Oko, A. E. Ndu, (2002). Economics Premises for Business Decisions. Enugu: John Jacob's Classic Publishers Ltd.

Oko, A. E. Ndu, \& Ogwo, E. O. (2012). Lease Service Marketing in Nigeria. Business and Management Review, 2(8), 15-26.

Oko, A. E. Ndu, \& Etuk, F. J. (2012). Risk Management in Nigeria the Lease Industry. Business and management Review, 2(8), 5-14.

Oko, A. E. Ndu. \& Aham, A. V. (2012). Problems of Equipment Leasing in Nigeria. Interdisciplinary Journal of Research in Business, 2(7), 1-11.

Olusoga, M. (2005). Development of Leasing in Nigeria. Banks Consolidation: Its Impact on the Leasing Industry. Leasing Today - A Quarterly Newsletter of Equipment Leasing Association of Nigeria, 9, 12-14.

O' Shea, J., \& Madiagn. (1997). Dangerous Company: The Consulting Power Houses and the Business they save and Ruin. New York: Times Books.

Stalk, G., Evan, P., \& Shulman, L. E. (1992). Competing on Capacities: The New Rules of Corporate Strategy. Harvard Business Review, March-April, 57-69.

Sandersonn, N. (2004). The Financing of Lease Companies. The Quest for an Enabling Environment for Leasing in Nigeria. Leasing Today - A Quarterly Newsletter of Equipment Leasing Association of Nigeria, 8(2), $32-35$.

\section{Copyrights}

Copyright for this article is retained by the author(s), with first publication rights granted to the journal.

This is an open-access article distributed under the terms and conditions of the Creative Commons Attribution license (http://creativecommons.org/licenses/by/3.0/). 